\title{
The Miracle of the Mesh: Global Imaginary and Ecological Thinking in Ralf Andtbacka's Wunderkammer
}

Kristina Malmio

In 2008 Finland-Swedish author Ralf Andtbacka, known for his postmodernist collections of poetry, published his fifth book entitled Wunderkammer. It is a book characterized by excess and heterogeneity. It includes poems which have the form of inventories and catalogues, poetry written in dialect, or created by using a search engine or poems generator, assemblages of objects, words, ways of speech and forms of language, sentences, fragments, genres, and styles. It experiments with the materiality of text, practices word-construction, word-destruction, and word-deconstruction and makes use of literary strategies typical of modernist and postmodernist poetry as well as procedural writing. It even incorporates and parodies theoretical discussions put forward by Karl Marx, Sigmund Freud, and Charles Darwin, and depicts the developments of the modern technology of reproduction. The reviewers defined Wunderkammer as a "sensual language bath" (Ekman 2008), and characterized it as "entertaining and humorous" (Hertzberg 2008). The overall topic, which combines the various poems

K. Malmio $(\square)$

University of Helsinki, Helsinki, Finland

(C) The Author(s) 2020

277

K. Malmio, K. Kurikka (eds.), Contemporary Nordic Literature

and Spatiality, Geocriticism and Spatial Literary Studies,

https://doi.org/10.1007/978-3-030-23353-2_13 
written according to various poetic conventions and practices, is that of objects and their relations to each other, and to the collector, the ways objects "behave" in collections, and the psychology and identity of the collector. Many of the poems consist of lists of various things, both real and invented.

Andtbacka not only experiments with language and objects; the book even includes an exhaustive variety and abundance of spatial forms, often described in a playful and self-reflexive manner. Already the title, Wunderkammer, signals an explicitly spatial form of art and science as it refers to an art historical tradition which evolved and flourished during the sixteenth, seventeenth, and eighteenth centuries. Cabinets of curiosities were rooms or cabinets filled with objects that the collector had gathered according to a special logic, the principle of pertinence (Ingvarsson 2015, 54-6). The title refers to this tradition of putting objects on display and makes the book a textual representation of the tradition. Moreover, the book contains the poems' visual and material play with the spatiality of the pages of the physical book, references to real geographical places from all over the world, descriptions of local milieus experienced by the writer, and depictions of general and abstract social, linguistic, cultural, and economic spaces as well as utopian and imaginary ones. It even depicts objects and technological, historical developments that have created connections between people far from each other, such as cables that unite continents, and objects that restore sound and knowledge, which can then be moved from one place to another.

The many objects and spatialities depicted in Wunderkammer are curious and striking, and raise questions: How is one to grasp the listed objects and the spatial heterogeneity and excess in it? From which (theoretical) perspective, then? What kind of spatial politics does it express? In order to answer these questions, I will concentrate on two recurrent forms of spatiality in Andtbacka's collection of poems: (1) "Wunderkammer" and (2) "Chinese box." "Wunderkammer," as mentioned above, goes back to a concrete, physical, and material form of spatiality, that of the closet, and to an art historical tradition. "Chinese box" is the term used of a set of boxes of graduated size, each fitting inside the next larger one. "Wunderkammer" and "Chinese box" have two traits in common: first, they propose a (traditional) form or pattern of how to organize objects in space, and, second, they refer on a semantic level to a limited space, a "container." These traits raise even more questions: How is one to understand Andtbacka's use of these forms which both suggest a bounded, physical-material, traditional form of space? Why now, in the twenty-first century? 
Traditionally, the difference between space and place has been defined as follows: space is an abstract entity which can be depicted in terms of volume, distance, and proportions, while place is a site loaded with (human) meaning, emotions, and attitudes - that is, space made meaningful by someone (see e.g., Cresswell 2004, 7-10; Prieto 2012, 12-14). However, during the last decades, earlier apprehensions of space have been profoundly questioned, problematized, and replaced by more complex views. The spatial turn has given birth to new ways to describe and understand space, including a growing awareness of space and its complexity, and the problems attached to it; there is a need for new spatial thinking connected to science, politics, and existence (Tygstrup $2015,303)$.

One of the scholars who has been of seminal importance for a novel approach to space is geographer Doreen Massey. As she points out, space is not static, but is "constructed out of interrelations, as the simultaneous coexistence of social interrelations and interactions at all spatial scales, from the most local level to the most global" (Massey 1992, 80). Space is the product of relations-between, the possibility of existence of multiplicity, and always under construction. The relational constructedness of everything includes even such "things" as identities and political subjectivities. Spatiality is also integral to the constitution of such identities in themselves, which in turn poses questions connected to geography (Massey 2005, 9-10). Thus, we need a geography of relations, and a fuller recognition of heterogeneity and multiplicity on a global scale, as she argues in For Space (Massey 2005, 9-15).

The idea of interrelatedness is pushed even further by Timothy Morton in The Ecological Thought (2010). What for Massey is (in particular social) interrelation, is interdependency in Morton's thinking, and includes not only human beings but everything: the ecological thought imagines the interconnectedness of all living and non-living things, the mesh (Morton $2010,15)$. The mesh, which usually designates one of the openings between the threads of a net, is here used in a manner that bears similarities with posthumanism and materialistic thinking. ${ }^{1}$ It consists of "infinite connections and infinitesimal differences" as "exchange and interdependence occur at all levels" (Morton 2010, 30, 36). ${ }^{2}$ A mesh has no absolute center, nor is there any distinction between background and foreground, inside or outside. It is shot through with uncanniness, gaps, and absent presences, made of insubstantial things, and populated by "strange strangers"- that is, by "something or someone whose existence we cannot 
anticipate" (Morton 2010, 42). The strange strangers might be animal, or us, or the environment (Morton 2010, 40-2). We live in the mesh because "we are the world" (Morton 2010, 119).

Ecological thought is, then, about thinking interconnectedness and totality, and “(...) a practice and a process of becoming fully aware of how human beings are connected with other beings-animal, vegetable, or mineral" (Morton 2010,7). The mesh includes all things and embraces an ethical attitude of profound coexistence. It is a new tool to think (and act) with, and strives to "(...) enable us to accommodate the strangeness-inintimacy and zooming shifts of scale required to more adequately reimagine the 'environment' and our relations with and within it" (Clark $2013,99)$. It is a perspective based on "connectionist" models of mind (Morton 2010, 115) and affects our ideas of spatiality in a far-reaching way. Namely, "the essence of the local isn't familiarity but the uncanny," as Morton declares $(2010,50)$. Morton is highly critical of Western thinking concerned with place, localism, and earth, and traditional ecological thinking of "nature" as something clearly defined, place-bound, limited, and based on a distinction between humans and non-humans. (Even) the environment should be thought of as a form of the "strange stranger," as something we cannot predict, something at the limit of our understanding (Morton 2010, 15-17), and the ecological thought needs to think of place as "anywhere," and extend our sense of location to include "anywheres" (Morton 2010, 55).

Morton's definition of "mesh" is, I think, highly inclusive, heterogeneous, and oppositional. He aligns far-flung fields, strives for an alliance between the humanities and the sciences (Watson 2013, 2), freely mixes ideas from Freud, Marx, Darwin, Derrida, and Levinas, just to mention a couple of his sources of inspiration, and criticizes polemically but at times on loose grounds earlier ecological or phenomenological thinking (Clark 2013). He constantly opposes his ideas to earlier research; what ecological thought is not becomes as important for his definition as his all-inclusive definition of what it is. It strikes me that "mesh" is not only a term created to describe a new way of thinking ecological interconnectedness but is also a description of the way in which Morton combines, mixes, and uses various theoretical, scientific, and artistic perspectives. Thus, rather than using "mesh" as an ordinary "tool" to analyze spatiality in Wunderkammer, I will read Morton's mesh and Andtbacka's spatial structures side by side in order to point out some similar features in their way of thinking about spatiality. The interconnectedness performed in Andtbacka's book is of 
the kind which reveals the uncanny "nature" of familiar things, places, and surroundings-Wunderkammer both produces uncanny space and makes room for the uncanny. But from the spatial perspective that focuses on the mesh, it also follows that a distinction between place and space comes to an end and gives room to something new.

In the following, I will argue that ecological thought is exactly what Andtbacka is up to in Wunderkammer. Curiously, probably the only themes that the book does not explicitly discuss are those of ecology and nature. That Wunderkammer's spatial politics is that of ecological thought becomes visible only after a careful scrutiny of it. Therefore, I will take a closer look at some examples of "Wunderkammer" and the Chinese box structure in a couple of poems, and, paraphrasing Morton $(2010,15)$, ask "Who or what is interconnected with what or with whom" in Wunderkammer.

\section{Collecting and Mapping the Old and the New WORLD}

Ralf Andtbacka is known as a language materialist, using letters, words, and language as material to be transformed, circulated, put together in new ways, according to various systematics, by accident or by a machine. American language poetry and in particular the work of poet John Ashbery (1927-2017) have been mentioned as important forerunners of Andtbacka's writing. It is from Ashbery that Andtbacka imports the postmodern long poem, which deliberately strives to avoid traditional poetical depth, a hidden meaning below the surface of the text produced by using symbols or other rhetorical figures (see, e.g., Gäddnäs 2009). Wunderkammer includes poems from various poetical traditions: modernist poems, procedural writing, postmodern poetry, and catalogue poems, an ancient poetical form which combines entertainment and knowledge (Hertzberg 2008), and so on. Many of the various features, which according to Brian $\mathrm{McHale}$ are recurrent in the postmodernist long poem and in Ashbery's works, are found in the book (McHale 2004, 142, 251-61).

The central theme of the book is collecting and writing about it, and the dominant milieus in which this activity takes place are the flea markets and shops in Vasa, a city on the West coast of Finland, and an old factory where the author has his working room. However, the objects depicted and enlisted enlarge the "narrated world" in a radical way; they create connections to far away geographical sites as they "float in" from everywhere in the world. 
Wunderkammer consists of six subdivisions, which have descriptive and at times enigmatic titles. The first part, called "Winks to collectors," focuses on the collector and his collections, and the second one, entitled "The spirit in the machine," depicts various forms of media, ways, and forms of how to store image, sound, and text. The third, "Persons and objects," the fourth, "The great chain of being," and the fifth called "Sweet Sistah Lockjaw," list names, languages, words, and objects. These more or less distorted objects are natural as well as produced by machines. The next part, "The new world," opens with the poem "Imago mundi" in which even the space surrounding the planet is included as the poem maps, among other things, even flying phenomena in the skies. In the poems of this part the reader comes across the Russian astronaut Yuri Gagarin, the voyages of discovery, dialogues on the internet and email messages, objects from around the globe, and poems about the West Atlantic Ocean as the author strives to find words to depict "the new world," which is so huge that it cannot be mapped with human measures. The last part of the book is entitled "Votivoffer" ("Votive gifts"), and it ends with the poem "12 assemblage (Svalbard)." After that, a couple of end poems are included.

Wunderkammer begins with descriptions of small, limited spatialities like boxes, caskets, and tiny rooms, but soon vast spaces like the universe enter the sphere of the book. The scale of the objects and phenomena depicted varies widely. In the poem "Jupiter" for example, the planet is mentioned side by side with the flea market named "Jupiter" in Vasa, the author's home town. The planet Earth also exists as a miniature object in the collection. The time span is immense: the poet imagines himself back in time to $1500 \mathrm{BC}$, but is also present in 2005 , the temporal dimension in the collection as a whole being as prevalent as that of spatiality (see e.g., Tally 2017, 1-2).

Postmodern spatiality and temporality are characterized by polytopy, "the composition of different spatialities," "space understood in its plurality," and by isotropy, "systemic indeterminacy" (Westphal 2011, 43, 37). In Wunderkammer both polytopy and isotropy occur. First, it is filled with spaces, and places of all kinds and on various levels, and second, the spaces and places depicted in it transgress all kinds of boundaries, mixing inside and outside, real and invented, material and symbolical, local and global. Thus, also the distinction between space and place comes to an end and ceases to be relevant. But having said that, the starting point is often an enclosed space, a room, or a box. 


\section{"Wunderkammer," Cabinets of Curiosities, and (The Ironic) Revival of Global Imaginary}

Repetition and the uncanny are the two defining features of the endless interconnections that make up what Morton calls the mesh. Repetition and the uncanny, "the strangely familiar and the familiarly strange" (Morton 2010, 50), also characterize the many occurrences of "Wunderkammer" in Andtbacka's book. Wunderkammer is not only the title of the book; it even includes several poems entitled "Wunderkammer," and the word "Wunderkammer" occurs in some of the poems. The repeated use of the word creates a semantic, thematic, material, and visual connectedness and brings together a geographical here and there. A closer look at the occurrences of "Wunderkammer" reveals its meshed features.

Despite the fact that Andtbacka's book is written in Swedish, the word "Wunderkammer" mostly appears in its German form, at times also in Italian and French. ${ }^{3}$ Thus, it is made strange in its Swedish linguistic context, but simultaneously the interconnectedness of the word to its other linguistic and geographical forms and existence in various European languages and areas is made explicit. The poems in which the word "Wunderkammer" occurs also take place in various geographical milieus, like Vasa, Svalbard, and Knaresborough in Yorkshire, to mention only a few. Moreover, "Wunderkammer" is even an email domain (wunderkammer.fi), a virtual "container" which resides in the "universe" of networks created by interconnected computers (Andtbacka 2008, 118).

At the beginning of the book, the word "Wunderkammer" enters into one of the eight paratexts, and offers an explanation of the content as well as the main structuring principle of the book. According to the paratext:

Det här verket ... är avsett att fungera som en ... Wunderkammer-ett kuriosakabinett-både till sin uppbyggnad och till sitt innehåll. Såsom är fallet med alla Wunderkammern, är det dess öde att fortsätta växa och förändras. Jag ser redan lakuner i min samling-och hela områden av nytt vetande som bör införlivas i framtiden. (Andtbacka 2008, 7)

This literary work ... is intended to function as a ... Wunderkammer-a cabinet of curiosities - when it comes to its structure and its content. As is the case with all Wunderkammers, its fate is to continue to grow and transform. I already see lacunas in my collections-whole areas of new knowledge that must be included in the future. (Trans. KM) 
Andtbacka's cabinet of curiosities is here openly connected to its art historical predecessors, both in terms of the objects included, and concerning the structure and logic of the way in which the objects are organized. It is also described as an organism; it grows and transforms.

The paratext declares that Wunderkammer imitates/simulates a tradition of collecting. In order to figure out if this really is the case, we must go back to the historical cabinets of curiosities. Horst Bredekamp in his study of cabinets of curiosities from the sixteenth to eighteenth centuries has described how these great collections of natural and human objects consisted of four categories. The first category, naturalia, included natural objects, such as minerals, and products made of minerals (like ancient sculptures), as well as specimens of vegetable and animal life. The second, artificialia, involved arts and crafts, refined objects made from organic and inorganic materials, giving the impression of dissolving the boundary between natural and human creations. The third category, scientifica, contained globes, watches, and other instruments for measuring and weighing, and the fourth, exotica, consisted of odd objects that could even be placed in every other category (Bredekamp 1995, 34-5). The collections and the various categories of the objects included served explicitly spatial aims. According to Bredekamp, Kunstkammers demonstrated a wish to understand "the earth in its horizontal, spatial entirety." He concludes:

Thus the Kunstkammer combined the three vertical stages of development-from naturalia to artificialia to scientifica - with a horizontal plane that represented efforts to research the entire globe. In a certain sense, then, the Kunstkammer were at one and the same time like time-lapse photography and microcosms of the world. (Bredekamp 1995, 36)

The closet represents/imitates/symbolizes the world and its development, and strives at the same time to copy and understand reality. A similar kind of world-mapping dimension is also obvious in Andtbacka's Wunderkammer as I will show later.

What or whom, then, are connected to who or what in Wunderkammer? In one of the opening poems, "Ting" ("Objects"), the poetic "I" lists objects and describes the significance of the things as they come together in a collection. Here the reader finds souvenirs ("arc de triomphe, big ben, den lille havfrue"), ${ }^{4}$ scrapbooks, mail order catalogues, spiral galaxies, and specks of dust, horns of unicorns, screws of certain kinds, "odds and 
ends." Moreover, fossils, various extinct groups of marine mollusks, "monsters of the imagination," as well as "an armful of stuffed birds" occur side by side with scrap, litter, remainders, flanges, feathers, "rotten mattresses," and odd machines that no longer work. All these objects are those that "you would take with you to a deserted island/bring back home from the deserted island" (Andtbacka 2008, 12).

Each poem in the first part of the book can also be seen as a "Wunderkammer" as they, like "Ting," consist of collections of objects. And indeed, as Jonas Ingvarsson observes in an article in which he studies Wunderkammer as an example of "digital epistemology" in literature (Ingvarsson 2015, 54), ${ }^{5}$ Andtbacka's book relates to the original cabinets of curiosities what comes to its associative logics and view of knowledge. What Ingvarsson does not pay attention to, however, is the fact that the relation of Andtbacka's Wunderkammer to cabinets of curiosities from the sixteenth, seventeenth, and eighteenth centuries is ironic. All the objects listed in "Ting" have one thing in common: they have no value/are not valuable in an ordinary sense. The objects are either rubbish, useless parts of things, unknown objects that can have no use or value, or things that do not exist. Thus, "Ting" is a collection of objects that you cannot own, or have no value or are impossible to value. Some of the objects found in the poem can be classified according to the categories of European cabinets of curiosities, but most of them are in opposition to the valuable objects in the collections of early modern times, at least those owned by princes and aristocrats, the rich and powerful (see Impey and MacGregor 2001, xix-xx).

Usually, you are supposed to take with you to a desert island only one or two things. By giving us the long list of objects, the poem depicts how humans surround themselves with objects and connect emotionally to objects. Obviously, the project of this cabinet of curiosities is similar to that of its predecessor, namely to research the entire globe, but now the global space is full of litter and strange objects, which are beyond the normal or expected. In reading the poem, the reader is confronted with and made aware of the simultaneous coexistence of strange strangers, all kinds of non-living things and beings that cannot be anticipated. The reader, moreover, is connected to them, and they are made meaningful to the reader: you are only supposed to list things that are especially valuable to you to take to a desert island.

In an interview from the time of the publication, Andtbacka explains his aims with Wunderkammer: 
We try to organize and arrange our living-space in a reality consisting of a chaotic overflow of objects/signifiers, but these spaces continuously leak, are undermined, vary. (...) To go through the garbage, the rubbish, the rest, the shit, is maybe a way to search for an alternative to, or maybe at least an opening in, the suffocating loss of alternatives characteristic to our time, in the middle of its supposed polyphony and pluralism. (Gäddnäs 2009; Trans. KM)

Morton uses the term "junkspace" to describe how in contemporary culture even space becomes junk, part of a throwaway culture (Morton 2010, 51 ). The presence of waste in "Ting" is not only an ironic comment upon the historical tradition of cabinets of curiosities, but also a depiction of “junkspace" produced by industry and automation (Morton 2010,53). And obviously, in the interview Andtbacka expresses a longing for a space that would be the opposite of junkspace.

On the final pages of the collection, the word and phenomenon of "Wunderkammer" is once again clarified. First, there is a short, historical explanation of how cabinets of curiosities arose in the sixteenth century during the era of voyages of discovery, due to the radical expansion of human knowledge connected to these voyages. The collections were ways to represent a macrocosm through a miniature cosmos, and strove to combine magic, knowledge, and aesthetics. Andtbacka's use of the tradition of the cabinets of curiosities suggests the similarity of our late modern era and that of the voyages of discovery. Then and now, cabinets of curiosities are used as tools for knowledge organization and interpretations of the world made through a spatial arrangement and a mapping of the objects included.

In the second part of the poem, Andtbacka connects historical cabinets of curiosities even more explicitly to his own time and place, that of the little room in which he writes in Vasa in the year 2005. During the process of writing, he explains, the room turned into an extension of the manuscript. It became filled with his findings from the seashore, various objects that the ocean had brought, and "thus partly connected to the cabinet of curiosities of the present age" (Andtbacka 2008, 144). For the author, Wunderkammer is a way to examine the phenomenon of collecting, and to study "objects as language, and language as object" (Andtbacka 2008, 144). He ends the last "Wunderkammer" poem by pointing out, paradoxically, that "to collect is to approach, object by object, what one is not" (Andtbacka 2008, 144). The page contains not only historical cabinets of 
curiosities, the room in which the author writes and the objects included in it, but it also connects to other contemporary cabinets of curiosities. All the various rooms and historical levels are interconnected as they occur (materially) on the same page. The examination of the world becomes an examination of oneself and of knowledge. The place and the text are connected to each other without any barriers as the author notices that "the room was soon transformed into an extension of the manuscript" (Andtbacka 2008, 144).

The occurrence of cabinets of curiosities, here revived in contemporary Nordic literature, is not as exceptional as one might at first think. ${ }^{6}$ Art historians and scholars of museology have lately noticed an enhanced interest in cabinets of curiosities in contemporary art as well as in museum exhibitions. Recently, cabinets of curiosities started to reappear in museums across the United States (Lasser 2015, 225-6). According to Ethan W. Lasser, the new popularity of this way of displaying objects is due to the fact that it invites the visitor to assume an active position as an examiner and interpreter of history, a position which "points to the deep relationships between today's cabinets and their Renaissance antecedents" (Lasser $2015,236-7)$. In the case of Andtbacka, I would rather argue that the traditional cabinets of curiosities have been adopted due to the way in which they illustrated a new view of nature. As Anthony T. Grafton (1995, xii) writes in his introduction to Bredekamp's book, cabinets of curiosities "emphasized the radical changes that nature underwent over time as its powers and resources were exploited in new ways." Here we witness a similar awareness of the exploitation of nature, but now combined with the endless amounts of waste, and a room which grows full of objects of various kinds and in which all limits between humans and nonhumans collapse. In traditional cabinets of curiosities as well as in Andtbacka's book, the microcosm is the picture of the macrocosm. The new view on nature put forward here is then that there is no nature.

But cabinets of curiosities had even further functions. The existence of cabinets of curiosities both in the past and in the present emphasizes the global circulation of knowledge, imaginary, objects, images, and ways of thought. Already during the era between 1400 and 1800, called "the first global age" by historians, a wide range of goods circulated across continents and global markets (Gerritsen and Riello 2015, 111). As Anne Gerritsen and Giorgio Riello argue: 
The spatial dimension of the so-called "first global age," however, should not be solely interpreted through the categories of physical geography. (...) it was also because people had the capacity to imagine and make sense of worlds beyond their own, something we call a "global imaginary." Artefacts and especially popular commodities had a significant role to play in the creation of this global imaginary. (Gerritsen and Riello 2015, 117) ${ }^{7}$

Obviously, following the tradition of cabinets of curiosities, Wunderkammer also functions as a global imaginary. Objects connect faraway places and people, and give access to "imaginative geographies" (Brosseau 2017, 13-14). Countless combinations of uncanny objects connect various places in the world, making here and there coincide. Thus, the meshed "nature" of Wunderkammer appears. This becomes even more obvious in the poem "Ask," which exemplifies the second spatial form to be studied here, the Chinese box.

\section{The Chinese Box: Meshing Together Objects Within OBJECTS}

The Chinese box is a recursive structure which is produced when you carry out the same operation over and over again, each time operating on the product of the previous operation. As an inherently spatial form and a recurring feature in postmodern literature, it is not surprising that the Chinese box structure also occurs in Andtbacka's collection (see McHale 1987, 112-30). The poems entitled "Wunderkammer" in the Wunderkammer collection are of course the most obvious examples of the structure. Chinese boxes make us aware of the strange logic of meshing on a structural and logical level, illustrating the endless interconnectedness of mesh and the way in which large and small, inside and outside, near and far lose their meanings as relative terms (Morton 2010, 39; Clark 2013, 103).

The poem "Ask" ("The box"), written according to the principle of "nesting or embedding" typical of a Chinese box, illustrates these ideas. The poem opens with a citation by Margaret Cavendish, Duchess of Newcastle (1623-1673), from a poem entitled "Of many worlds in this world," which in itself is an example of the structure of Chinese boxes.

In "Ask," we have a list of objects included within each other. On the opening line a spatial paradox immediately arises: Andtbacka's poem titled after a small defined space ("ask" in Swedish means "box," but is also the name of a tree, the ash) begins with "The universe," designating a limitless space or world: 
UNIVERSUM är en grön onyxsköldpadda.

Inuti sköldpaddan finns en mindre sköldpadda.

Inuti den lilla sköldpaddan finns en balinesisk danserska skuren i trä.

Inuti danserskan finns en leksakssnurra av fabrikatet Lorenz Bolz.

Inuti snurran finns ännu en träfigur, med en guldfärgad klisteretikett:

Kwakiutl medicine man. Made in Canada. Thorn Arts, Nanaimo, B.C.

Inuti indianen finns en lätt bucklad tennask köpt på en loppis i Storuman.

Inuti tennasken finns en japansk munk, i rödlera, som visar pitten.

Inuti munken finns ett reklamfat (diameter: tio centimeter):

Björns Glas • Porslin AB. Solna centrum 30.11.1962.

Inuti fatet finns en ödla i täljsten.

Inuti ödlan finns nästa ask.

Den är snidad av Elis, Elis Ask.

... (Andtbacka 2008, 9)

THE UNIVERSE is a green turtle made of onyx.

Within that turtle there is a smaller turtle.

Within the little turtle there is a wooden carved dancer from Bali.

Within the dancer there is a pinwheel manufactured by Lorenz Bolz. ${ }^{8}$

Within the pin wheel there is one more wooden figure, with a golden label on it:

Kwakiutl medicine man. Made in Canada. Thorn Arts, Nanaimo, B.C.

Within the Indian there is a slightly buckled tin box bought at the flea market in Storuman. ${ }^{9}$

Within the tin box there is a Japanese monk in clay showing his prick.

Within the monk there is an advertising dish (diameter: ten centimeters):

Björns Glas • Porslin AB. Solna centrum 30.11.1962. ${ }^{10}$

Within the dish there is a lizard made of soapstone.

Within the lizard there is the next box.

Which is carved by Elis, Elis Ask. /

... (Trans. KM)

Within the small box, an enormous universe is included, a row of structures within structures strangely closed by the surname of the Swedish carver. "Ask" is a closed space, which at the end "returns" to its origin, the creator Elis Ask, humorously also the name of a Finnish boxer (1926-2003). The closed structure contains, however, phenomena that are basically impossible to grasp or limit. Also the three periods at the end of the poem indicate its openness. Further on in the collection, the closed spaces depicted become more and more porous, as objects and phenomena flow across all limits and barriers. Thus, the meshed features of the spatiality depicted become more and more obvious. But here, still, the Chinese box, a repetitive spatial structure, is left untouched, and its uncanny, artificial features are visible. 
Between the opening and the end of the poem, a catalogue of embedded objects of various kinds occur: valuable things, toys, souvenirs, kitsch, curious objects, and all man-made. During the Renaissance in Italy, cabinets of curiosities were single rooms, extravagant, fanciful spaces displaying the rare and unusual artifacts that belonged to elites (Lasser 2015, 226). Hence "Ask" like "Ting" provides an ironic response to traditional cabinets of curiosities, as the objects in it are, again, mostly rubbish, souvenirs, and kitsch. Instead of a room, we have here a box; instead of treasures and valuables, Andtbacka lists souvenirs of cheap materials, objects of everyday mass production from all over the globe for the "masses" of the world.

The depicted objects refer to various parts of the world. As a form of mapping, Wunderkammer connects places with vast geographical distances, spaces and places from far away and near. And here again, as in "Ting," the journeys these objects make and their relations to each other create interconnections between different parts of the globe, in a similar way as the objects in the early cabinets of curiosities did. The objects circulate globally, a movement described by Andtbacka especially in Part 1 "Hints for collectors." Through the movements of these obviously useless objects manufactured in various parts of the world, the reader is invited to imagine and reflect upon global market capitalism (see also Malmio 2017). Wunderkammer is, then, not only a means of understanding the world and expanding knowledge, but also an archive of global commerce. And simultaneously it shows how utterly strange the objects produced and circulating are as well as the interconnectedness of "us" to everything else, living and dead, in the mesh.

But, even more important, "Ask" reveals a meshed form of knowledge and logic related to spatiality. A Chinese box is an uncanny form of spatiality (see McHale 1987, 126), raising a question: How it is possible that the objects listed might be contained within each other? As Ingvarsson suggests, Andtbacka's book follows the logic of early modern cabinets of curiosities, which were created according to a playful, associative logic, the "principle of pertinence" (Ingvarsson 2015, 53-4). Wunderkammer, the tradition of cabinets of curiosities as well as Chinese boxes are spatial arrangements that question the principle of provenance, and that of origin and development (Ingvarsson 2015, 54). But they also resist and question a Western scientific understanding of sizes and dimensions of objects in space. Thus, the Chinese box structure offers a similar kind of alternative to the modern project as the cabinet of curiosities. 
The space created in "Ask" is characterized by a high degree of interconnectedness of both the objects and the structure; they are all included within each other. The way in which the objects are linked to each other and the repetition connected to the Chinese box together strengthen the uncanny features of the poem. "Ask" is a strange box indeed, a paradoxical form of spatiality which can include both very huge and very small things and phenomena, all included within each other along repetitive lines. Thus it overthrows the relation of inside-outside in a manner characteristic of mesh. Similarly, another "Wunderkammer" poem shows the uncanny "unnatural" and threatening floating together of subject and object, human being and thing (Andtbacka 2008, 135). The radical interconnectedness of ecological thought means that exchange and interdependency occur at all levels (Morton 2010,36). The way in which Andtbacka uses the Chinese box structure demonstrates this with an almost pedagogical clarity.

Wunderkammer thus performs "enmeshed" thinking. In it, the traditional spatial markers of up-down, out-in, exterior-interior, centerperiphery, near-far, national-international, familiar-strange, subject-object have expired, or at least are questioned, as I will show in yet another "Wunderkammer" poem.

\section{The Wonder of the Wunderkammer: The Uncanny Oddness of THE Ordinary and THE EXTraordinary}

In the next poem entitled "Wunderkammer" (Andtbacka 2008, 50-1), the miracle of the cabinet of curiosities is finally explained when the author describes what happens in artistic creation. "Even I sometimes get the question what makes me write. Let me explain," he states at the beginning of the poem. The writer/narrator in the poem then starts to depict the view from his work room desk of a gym in another part of the old factory building where he works. What he sees is strange: he has a partial view of people doing their exercises at various apparatuses; what he sees are merely their legs. Legs running on running carpets, using exercise bikes, training the muscles of the inner thighs in chairs looking like those a gynecologist would use-all this is described as a "concert of anonymous movement" (Andtbacka 2008, 50). He comments upon the activities he sees: "it might not be preposterous to imagine that such a collective muscle energy must not be lost, but gives force to alchemical generators." He then describes 
how the power produced by the exercisers at the gym is connected to various kinds of cables, both old-fashioned and new, which force their way through the walls of the building, and continue all the way through the earth's crust to the earth's core. There, they make a U-turn to return, making their way up to his part of the factory, through the corridor on the third level, and opening up a door on which "Wunderkammer" is written in white letters against a black background. Having forced their way into the room, the cables sneak up to the author where he sits by his table facing his computer, and connect to his brain. "This is roughly how I imagine it all," he closes the poem (Andtbacka 2008, 51).

The poem consists of ten verses of three lines each, plus a final closing line. The depiction of the flow of energy from beginning to end, combined with the narrative form of the poem, gives the impression of movement from one verse to the next. The lines of the poem also "flood" from one verse to the next, as the lines do not end with a full stop but with a semicolon or period. A natural law, namely that energy can never be destroyed but can only change form, is here transformed into a strange and humorous psychological-mechanical-material-technological-artistic process in which the energy from the machines in the gym enters the brain of the poet and makes him write. The text created is the product of a compilation of human and machine energy. In a mysterious and odd manner, this energy makes its way through all kinds of walls and surfaces, no matter whether they are buildings, earth crust, or a skull.

This is, I think, a fine description of the interconnectedness of an author and artistic creation, between near and far, inner and outer, machines and bodies, technology and nature, performed here and now, in the poem. Once again, the spatial form is that of a box within a box, as the poem "Wunderkammer" includes a room entitled "Wunderkammer." The gym, which also has the form of a box, now includes living physical bodies. The poem, moreover, makes ordinary, familiar practices like exercising, viewing, working, and writing strange and defamiliarized. As in traditional cabinets of curiosities the interconnectedness of objects is emphasized by displaying objects side by side in the same "room" in combinations that resist ordinary logic. The oddness of the way energy moves in the poem enhances the strangeness of the ordinary objects on display, thus questioning the commonplace way of seeing, combining, comparing, classifyingthe scientifically based reasonable way of making sense of the world around us. The uncanny, unnatural character of the mesh appears as the poem imagines the interconnectedness of alchemy, technology, the planet, and 
the individual. Alchemy is a historical form of producing miracles, technology the current one, art still another form. Here "Wunderkammer" becomes a space where miracles take place.

In a similar uncanny manner, the connections between the author, language, identity, and place are deconstructed. Vasa in the region of Ostrobothnia is the central milieu of the collection, the place where Andtbacka and his family live and belong. The region is also the home of several other important Finland-Swedish authors. In a procedural poem, this local spatial dimension is interconnected to digital technology, algorithms producing the author's text. The introductory poem that opens the "Suite Ostrobothnienne (un cabinet de curiosités)" (Andtbacka 2008, 78 ), is created by putting the name of the author Ralf Andtbacka into a poetic generator. This results in two pages of variations and repetitions of letters and syllables based on the word "ralf" combined with random chosen words in alphabetic order from a dictionary, and ending with the comment "Word meld" (Andtbacka 2008, 80). Automation, machine, repetition, and the author come together and produce-again-interconnectedness, on several levels at the same time. If repetition and automation are the central features of the uncanny, we have here a poem which is truly uncanny. Not only is it throughout structured by a machine/algorithm based on breaking down and repetition, but also the way it breaks into pieces the author's identity marker, his name, is a prime example of destruction and deconstruction. It comments on the unique status of an author as a creating individual, with his name as an artistic "trade mark" or guarantee of style and quality of writing. Altogether, the word mix produces not only a form of erasure at the level of both language and projected world, but is also an example of aleatory and mechanical procedures typical of postmodernist poetry (see McHale 2004, 253).

After having erased the name of the author himself, the Ostrobothnian cabinet of curiosities continues by listing "I Poètes ostrobothniens," including names of more or less known national and international people, among them Darwin, Frankenstein, and "Lasr Hrulldén," a corrupted form of the name of another Finland-Swedish Ostrobothnian author Lars Huldén (1926-2016). By including Kafka, Mayakovski, and John Ashbery among Ostrobothnian authors, Andtbacka turns inside out the relation between center and periphery, local and global. In the following parts, "II Dialectes suédois en Ostrobothie," "III Fétisches ostrobothniens," and "IV Essences ostrobothniennes," absurd combinations of adjectives, objects, and forms of grammar are included and described as essential to 
the area depicted. Uncanny, strange, and foreign too are the collections put together under the title "Ostrobothian," an area that is familiar and local for Andtbacka. This of course comes close to the ecological thought that aims to defamiliarize what we usually perceive to be familiar and local surroundings.

Finally, the word "Wunderkammer" is part of the language material manipulated by the author. The word and the collection turn at the end of the book into material objects, which during reading become more and more fragmented, as if they were pieces of nature in a process of decay. This is evident in the last poem of the collection, " 12 assemblage (Svalbard)," which also includes a commentary upon the ideas of Darwin as well as a parody of our thoughts of development as progress. The poem includes a metaliterary statement on the process of the collection, as it states that "this. book" is about to reach its "qlrhfqöu" as it has not achieved "öwjhöowhqewäivjewsvjqevp" for several weeks. The poem simulates an organic and/or digital development taking place, using fragments of words that are only partly possible to identify: "wrundrkammer. hålle.rr på/att. Gjyttra in i. ett murkr. av lqiurujthester./utan inbördes/ hjord./ning" ("wrundrkammer. is abou.tt./to. Chlusster together. into a rotte.n. lqiurujthester./without an inner/hjord./er") (Andtbacka 2008, 138; Trans. KM). The word "Wunderkammer" turns into a muddle or something rotten. This development erases the differences between digital and organic, machines and nature, text and world.

The basis of ecological thought is Darwin's theory of evolution (Morton 2010, 30). According to Morton (2010, 8), it is not surprising that we come across "unnatural" beings in ecological thinking. After all, “(...) what we call 'nature' is a 'denatured,' unnatural, uncanny sequence of mutations and catastrophic events: just read Darwin” (Morton 2010, 8 ). In evolution things do not disappear, they become vestigial or mutate. Morton then draws parallels between Darwin's ideas of evolution and art. Uncertainty, variety, and continuity are characteristic features of both evolution and language and stand for continuity and change, he argues (Morton 2010, 65-6). These ideas find their counterpart in Andtbacka's mutations of words. The seemingly organic process that takes place in the poem illustrates how art and nature are similar things which develop side by side. The poem makes the falling apart of the world it has created obvious, and the artificiality of both art and nature evident. 


\section{CONCLUSION}

There are many forms of "Wunderkammer" in Ralf Andtbacka's collection of poetry, as I have shown above. "Wunderkammer" is a (material) word, collections of different kinds, a historical genre, the name of the working room of the author, a digital domain, a word and a collection that is about to become rotten. Both cabinets of curiosities and Chinese boxes are limited spatial forms, but what characterizes Andtbacka's use of them in Wunderkammer are the various ways in which the spatial structures "flow" over their limits. When one studies the various forms of spatiality in Wunderkammer, it becomes obvious that (one of) the miracles that takes place here is the transformation of all kinds of containers and boxes into open and porous spaces, and finally into a textual representation of mesh. Both the "Wunderkammer" and the Chinese box structures illustrate the radical interconnectedness of the objects and phenomena depicted. Thus Wunderkammer shows many similar features to the notion of mesh as put forward by Timothy Morton.

Even the uncanny nature of mesh is demonstrated in Wunderkammer. The repetition of words and absurd chains of fragments and objects end in a representation of the depicted phenomena in "decay," as something which is becoming rotten, something organic and chaotic, and beyond reason. The order of no-order and the interconnectedness of everything are the result of the "progress" of this book. The ideas of "evolution" and "development," thought of as being something logical and progressive and leading to better and more rational forms of existence, are destroyed and at times even deconstructed. This repetition, produced for example by poetry engines, presents an uncanny portrayal of signification beyond signification.

I have focused in this chapter on two spatial forms in this postmodernist collection of poems, and interpreted them as ways of thinking "enmeshed," as ecological thought. I have argued that mesh is found especially by focusing on its spatial forms. Wunderkammer is literally saturated with all forms of spatiality and "strange strangers," and the interconnectedness of everything living and dead, organic and not organic is demonstrated on various levels. Morton $(2010,55)$ points out: "The idea of authentic place is a powerful Western myth." Obviously, the cabinets of curiosities are already such rooms, which were highly artificial, and in the eyes of us now, "enmeshed," as they included very rare objects and combined them according to a logic which has long been lost in Western scientific and aesthetic thinking. Therefore, the tradition of cabinets of 
curiosities offers a kind of model for the interconnectedness of all things. This tradition from the first global era is updated to the twenty-first century by Andtbacka and pushed even further-the spaces and places Wunderkammer constructs are all artificial. The project of the book is partly that of deconstructing Western ideas concerning the authenticity of place.

"In the future, people might see what we now call postmodern art and culture as the emergence of global environmental culture," Morton (2010, 19) states. In Wunderkammer, at least, ecological thought is already fully present. The way in which spatiality is created in Wunderkammer points toward an awareness of the spatial turn, a development of the late twentieth century, but it is even pushed further. The global space that has been under construction since journeys of exploration began is here depicted as "junkspace," full of rubbish and waste. Thus, I argue that Wunderkammer shows an awareness of spatiality which goes beyond a merely artistic or "global" perspective. The way in which the collection proposes spatiality as a form of heightened interconnectedness refers to a recent development within spatiality, namely a planetary turn. In this approach, research turns away from the globe, apprehended as a financial-technocratic system, toward the world ecology of the planet, building on a relationality model and a return to ethics (Elias and Moraru 2015, xvi-vii). In this re-orientation, our planet becomes increasingly the conceptual and political dimension in which twenty-first-century writers and artists situate themselves and their work. It sees "the planet as a living organism, as a shared ecology, and as an incrementally integrated system both embracing and rechanneling the currents of modernity" (Elias and Moraru 2015, xii; italics original). After all, the spatial forms of Wunderkammer not only comment upon globalization, but also perform ecological thinking by showing the enmeshed interrelatedness of all things and spaces.

\section{Notes}

1. Despite the obvious similarities between ecological thinking and posthumanism, Morton argues that ecological thinking escapes posthuman "ideological barriers" (Morton 2010, 113).

2. Morton writes that he prefers "mesh" instead of "web" because web is "a little bit too vitalist and a little bit Internet-ish" (Morton 2010, 28).

3. The Swedish word for cabinet of curiosities is "kuriosakabinett."

4. The little mermaid, which here probably refers to the statue in Copenhagen of the protagonist from the fairy tale by Danish author H.C. Andersen. 
5. Jonas Ingvarsson analyzes Andtbacka's collection as an example of "digital epistemology," a critical discourse analytic and media archeological concept that strives to open up new perspectives on the present aesthetic and cultural world and history. He argues that digital archeology and the aesthetics of the cabinets of curiosities have several traits in common, namely the combination of a manifest materiality, and an associative and aesthetic practice, a playful science in which knowledge is created through free associations rather than systematic logic (Ingvarsson 2015, 47-8).

6. I would like to thank Thomas Mohnike, who called my attention to this at a research seminar at Humboldt-Universität zu Berlin, NordeuropaInstitut, May 2017, when I presented my paper on Andtbacka.

7. This description of the way in which objects link various places to each other differs from the "imaginative geographies" discussed by Marc Brosseau (2017, 13-14). Being a concept originally put forward by Edward Said, "imaginative geographies" refer to a complex web of power relations connected to colonialism and imperialism which can be studied in literary texts.

8. A German toy factory.

9. A municipality in Northern Sweden.

10. The name of a Swedish manufacturer of items made in glass and porcelain.

\section{REFERENCES}

Andtbacka, Ralf. 2008. Wunderkammer. Dikter. Helsingfors: Söderströms.

Bredekamp, Horst. 1995. The Lure of Antiquity and the Cult of the Machine: The Kunstkammer and the Evolution of Nature, Art and Technology. Translated by Allison Brown. Princeton: Markus Wiener Publishers.

Brosseau, Marc. 2017. In, of, out, with, and through. New Perspectives in Literary Geography. In The Routledge Handbook of Literature and Space, ed. Robert T. Tally Jr., 9-27. London and New York: Routledge.

Clark, Samantha. 2013. Strange Strangers and Uncanny Hammers: Morton's The Ecological Thought and the Phenomenological Tradition. Green Letters: Studies in Ecocriticism 17 (2): 98-108. https://doi.org/10.1080/14688417. 2013.800339.

Cresswell, Tim. 2004. Place: A Short Introduction. Oxford: Blackwell Publishing. Ekman, Michel. 2008. Sensuella språkbad. Hufiudstadsbladet, September 23.

Elias, Amy J., and Christian Moraru. 2015. Introduction: The Planetary Condition. In The Planetary Turn: Relationality and Geoaesthetics in the Twenty-First Century, ed. Amy J. Elias and Christian Moraru, xi-xxxvii. Evanston, IL: Northwestern University Press.

Gäddnäs, Katarina. 2009. Poesin utanför marknaden. Nytid, October 22. 
Gerritsen, Anne, and Giorgio Riello. 2015. Spaces of Global Interactions: The Material Landscapes of Global History. In Writing Material Culture History, ed. Anne Gerritsen and Giorgio Riello, 111-133. London, Oxford, New York, New Delhi, Sydney: Bloomsbury Academic.

Grafton, Anthony T. 1995. Introduction. In The Lure of Antiquity and the Cult of the Machine, ed. Horst Bredekamp, xi-xiii. Princeton: Markus Wiener Publishers.

Hertzberg, Fredrik. 2008. Lika kuriöst som kompromisslöst. Svenska Dagbladet, November 21.

Impey, Oliver, and Arthur MacGregor. 2001. Introduction. In The Origins of Museums: The Cabinet of Curiosities in Sixteenth- and Seventeenth-Century Europe, ed. Oliver Impey and Arthur MacGregor, xvii-xx. Oxford: Clarendon Press.

Ingvarsson, Jonas. 2015. BBB vs WWW. Digital epistemologi och litterär text från Göran Printz Påhlsson till Ralf Andtbacka. Tidskrift för litteraturvetenskap 1: 45-60.

Lasser, Ethan W. 2015. The Return of the Wunderkammer: Material Culture in the Museum. In Writing Material Culture History, ed. Anne Gerritsen and Giorgio Riello, 225-239. London, Oxford, New York, New Delhi, Sydney: Bloomsbury Academic.

Malmio, Kristina. 2017. De tings must be in order. Den de coustumers buy better. Kapitalismkritik i Ralf Andtbackas diktsamling Wunderkammer. In Modernitetens uttryck och avtryck: Litteraturvetenskapliga studier tillägnade professor Claes Ablund, ed. Anna Möller-Sibelius and Freja Rudels, 138-148. Åbo: Föreningen Granskaren.

Massey, Doreen. 1992. Politics and Space/Time. New Left Review 1 (196): 65-84. . 2005. For Space. London: Sage.

McHale, Brian. 1987. Postmodernist Fiction. London and New York: Routledge.

- 2004. The Obligation Toward the Difficult Whole: Postmodernist Long Poems. Tuscaloosa and London: University of Alabama Press.

Morton, Timothy. 2010. The Ecological Thought. Cambridge, MA: Harvard University Press.

Prieto, Eric. 2012. Literature, Geography, and the Postmodern Poetics of Place. New York: Palgrave Macmillan.

Tally, Robert T., Jr. 2017. Introduction: The Reassertion of Space in Literary Studies. In The Routledge Handbook of Literature and Space, ed. Robert T. Tally Jr., 1-6. London and New York: Routledge.

Tygstrup, Frederik. 2015. Plats. In Litteratur: Introduktion till teori och analys, ed. Lasse Horne Kjælgaard, Lis Møller, Dan Ringgaard, Lilian Munk Rösing, Peter Simonsen, and Mads Rosendahl Thomsen, 301-310. Lund: Studentlitteratur.

Watson, Matthew C. 2013. Ecological Thought (Review). Interstitial Journal (May): 1-5.

Westphal, Bertrand. 2011. Geocriticism: Real and Fictional Spaces. Translated by Robert T. Tally Jr. New York: Palgrave Macmillan. 
Open Access This chapter is licensed under the terms of the Creative Commons Attribution 4.0 International License (http://creativecommons.org/licenses/ by $/ 4.0 /$ ), which permits use, sharing, adaptation, distribution and reproduction in any medium or format, as long as you give appropriate credit to the original author(s) and the source, provide a link to the Creative Commons licence and indicate if changes were made.

The images or other third party material in this chapter are included in the chapter's Creative Commons licence, unless indicated otherwise in a credit line to the material. If material is not included in the chapter's Creative Commons licence and your intended use is not permitted by statutory regulation or exceeds the permitted use, you will need to obtain permission directly from the copyright holder.

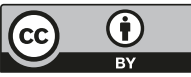

